\title{
MAGNESIUM METABOLISM IN HEALTH AND DISEASE. I. THE MAGNESIUM AND CALCIUM EXCRETION OF NORMAL INDI- VIDUALS, ALSO THE EFFECTS OF MAGNESIUM, CHLORIDE, AND PHOSPHATE IONS
}

\author{
By DOROTHY M. TIBBETTS AND JOSEPH C. AUB \\ (From the Medical Laboratories of the Collis P. Huntington Memorial Hospital of Harvard \\ University, Boston)
}

(Received for publication December 22, 1936)

Much attention has been paid in recent years to inorganic salt metabolism. Great advances in our knowledge have been made in regard to the exchange of calcium and sodium, but a surprising ignorance remains in respect to the magnesium exchange. Magnesium is obviously an important constituent of the body for it appears to be universally present, and physiological changes result from magnesium starvation (1). In spite of the fairly close chemical relationship between calcium and magnesium, their relative distribution in body tissues is widely divergent. Roughly, one may state that under normal conditions magnesium tends to be higher than calcium in the cells of soft tissues, while calcium is higher than magnesium in extracellular fluids and in bones. This distribution would make one anticipate that their physiological actions were of different nature, and there is, of course, physiological evidence that sometimes at least their effects are antagonistic. It is, therefore, of interest to see whether the influences which affect calcium metabolism have analogous effects upon magnesium exchange. This is the purpose of the following papers.

From the literature one finds that the concentration of magnesium in body tissues has been studied but little. A good summarizing table of recorded data is given in the recent review by Schmidt and Greenberg (2). The most complete study in man was done by Magnus-Levy in 1910 (3). He studied the inorganic salt content of most of the tissues obtained from a suicide. In the muscles he found magnesium in far greater amounts than calcium, the ratio being approximately $3: 1$, but in the internal organs there was considerable variation in the ratio, and he found more calcium than magnesium in the skin, thyroid, and lungs. More recent analyses of muscle with improved technic have been reported by Cullen,
Wilkins and Harrison (4), showing variations in calcium and magnesium concentrations in different parts of heart muscle but with the magnesium always two or three times the weight of calcium. Sherman (5) states that in meat 100 grams of muscle protein averages $58 \mathrm{mgm}$. of calcium and $118 \mathrm{mgm}$. of magnesium. Expressed in milliequivalents $(\mathrm{Ca}=29, \mathrm{Mg}=97)$, this would make the difference in concentration even more pronounced. Recent work by Greenberg, Lucia, Mackey and Tufts (6) on the magnesium content of the red corpuscles in human blood showed that they contain an average of $6.6 \pm 0.5 \mathrm{mgm}$. of magnesium per $100 \mathrm{ml}$. of corpuscles. The concentration of calcium in blood cells, on the other hand, is extremely small.

In blood serum and in bones this high concentration of magnesium is not found. In the serum of normal individuals the average value of magnesium in our experience is between 2.4 and $2.8 \mathrm{mgm}$. per $100 \mathrm{cc}$. of serum. This agrees quite well with the values from other laboratories. The calcium:magnesium ratio of bone is variously given. In normal dried bone McCrudden (7) found this ratio to be essentially 1:0.005 with a much higher relative magnesium concentration in osteomalacia. Euler and Rydbom (8) give the calcium: magnesium ratio of normal bone ash as 24 parts of calcium to 0.1 part of magnesium and that of rachitic bone as about 21 parts of calcium to 0.6 part of magnesium. Morgulis (9), analyzing the bone ash of various animals, found that the relative concentration of calcium and magnesium differed with the species. The ash of bones of the dog and rabbit he reports as 36 per cent calcium to 0.5 per cent magnesium.

From these concentration ratios of magnesium and calcium, which vary so much in different body tissues, one may obtain approximate evidence of 
the source of these bases when they are eliminated by the body. If the loss comes entirely from the bone, then the magnesium excretion will be negligible compared with that of calcium; if from the tissues, the magnesium elimination will be the larger. As an example, it was shown by Benedict (10), that in starvation the calcium elimination was approximately four times that of magnesium by weight. This is a ratio unlike that found in the analysis of either bone or tissue. The amount of magnesium would indicate a destruction of the soft tissues but the relatively large amount of calcium eliminated could not be accounted for in this way. In fact, on the basis of the calcium:magnesium ratio, 90 per cent of the calcium must come from the catabolism of bone.

Therefore, it would seem reasonable to assume that changes in magnesium excretion would be slight in cases of bone growth or destruction, but that processes involving tissue catabolism would show more change in magnesium than in calcium excretion.

\section{EXPERIMENTAL METHODS AND PROCEDURES}

The normal requirements of man for magnesium have not been thoroughly studied. An edible diet which is low in magnesium would have to be high in calcium because the foodstuffs involved would consist largely of milk products and eggs. In most of our observations, we have used a low calcium diet such as we have employed in the past (11). It has a moderate magnesium content of about $220 \mathrm{mgm}$. per day. This is two or three times the amount excreted during the prolonged starvation in Benedict's study (10), but is below the average (340 mgm.) found by Sherman (5) in 150 American dietaries. We may, therefore, assume that our diets are adequate in their magnesium content though inadequate in calcium. In some observations on the effect of magnesium feeding, we have used ample magnesium and calcium in the diet in order to observe effects on positive as well as on negative balances. All of the diets were potentially neutral and were analyzed in the laboratory for calcium and magnesium.

Our usual metabolic regime as described in a former paper (11) was followed throughout, and the methods of analyses were essentially the same. Calcium determinations were made by the method of Fiske and Logan as described by Folin (12). In the samples which contained large amounts of magnesium in proportion to the calcium, the determinations were repeated, using the double precipitation method of the same authors (13). As the results were practically identical with those obtained by the former method, we felt satisfied that none of the magnesium was being precipitated with the calcium even though a large amount was present in the sample.

The magnesium determinations were also made by the methods of Fiske and Logan (12). We have used both the colorimetric and the alkalimetric titration methods in these studies, and determinations made on the same sample by the two methods agreed within 3 per cent. When the sample contained a large amount of calcium in proportion to the magnesium, most of the calcium was precipitated as its oxalate salt in a solution acid to methyl red. After removal of this precipitate, the solution was brought to $\mathrm{pH} 4.8$ to 5.0 and the remainder of the calcium oxalate filtered off and the filtrate analyzed for magnesium in the usual way.

Whenever calcium or magnesium was present in large excess, the determinations were carried out independently of each other.

\section{EXPERIMENTS}

From Table I and the control periods of Tables II and III, it is clear that the magnesium excretion on our type of neutral diet, on the whole, is the same by weight as that of calcium, and that approximately one-third of the total excretion of either base is to be found in the urine. Magnesium is more constant in this regard than is calcium.

Table I also demonstrates that on an intake of $220 \mathrm{mgm}$. of magnesium daily, some individuals living in the hospital ward will be in negative, some in positive balance. Thus, in $\mathbf{1 5}$ periods in five individuals, the average magnesium balance was $50 \mathrm{mgm}$. per three-day period and in only one case in five was the magnesium balance negative. There were in addition four other normal controls who were medical students pursuing their normal activities, except that all their meals were carefully prepared in the research diet kitchen (A. D. and C. W., Table I ; M. L., Table II ; and R. L., Table III). They were given a constant 
TABLE I

Normal subjects*

(Intake and output in 3-day periods)

\begin{tabular}{|c|c|c|c|c|c|c|c|c|c|}
\hline \multirow{3}{*}{ Subject* } & \multirow{3}{*}{ Period } & \multicolumn{4}{|c|}{ Magnesium } & \multicolumn{4}{|c|}{ Calcium } \\
\hline & & \multicolumn{3}{|c|}{ Excretion } & \multirow{2}{*}{$\underset{\text { take }}{\text { In- }}$} & \multicolumn{3}{|c|}{ Excretion } & \multirow{2}{*}{$\begin{array}{c}\text { In- } \\
\text { take }\end{array}$} \\
\hline & & Urine & Feces & Total & & Urine & Feces & Total & \\
\hline 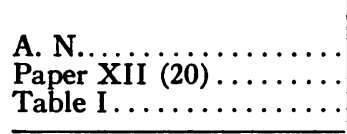 & $\begin{array}{l}\text { III } \\
\text { IV } \\
\text { V }\end{array}$ & $\begin{array}{c}\text { grams } \\
.35 \\
.25 \\
.27 \\
\end{array}$ & $\begin{array}{c}\text { grams } \\
.45 \\
.47 \\
.49\end{array}$ & $\begin{array}{c}\text { grams } \\
.80 \\
.72 \\
.76 \\
\end{array}$ & $\begin{array}{c}\text { grams } \\
.66 \\
.66 \\
.66\end{array}$ & $\begin{array}{c}\text { grams } \\
.18 \\
.19 \\
.16\end{array}$ & $\begin{array}{c}\text { grams } \\
.15 \\
.18 \\
.16\end{array}$ & $\begin{array}{c}\text { grams } \\
.33 \\
.37 \\
.32\end{array}$ & $\begin{array}{c}\text { grams } \\
.31 \\
.31 \\
.31\end{array}$ \\
\hline $\begin{array}{l}\text { B. E. } \ldots \ldots \ldots \ldots \ldots \ldots \\
\text { Paper XiI }(20) \ldots \ldots \ldots \ldots\end{array}$ & $\begin{array}{l}\text { II } \\
\text { III } \\
\text { IV } \\
\text { V }\end{array}$ & $\begin{array}{l}.27 \\
.24 \\
.24 \\
.25\end{array}$ & $\begin{array}{l}.49 \\
.20 \\
.34 \\
.34\end{array}$ & $\begin{array}{l}.76 \\
.44 \\
.58 \\
.59\end{array}$ & $\begin{array}{l}.74 \\
.72 \\
.72 \\
.72\end{array}$ & $\begin{array}{l}.10 \\
.13 \\
.15 \\
.18\end{array}$ & $\begin{array}{l}.47 \\
.16 \\
.24 \\
.25\end{array}$ & $\begin{array}{l}.57 \\
.29 \\
.39 \\
.43\end{array}$ & $\begin{array}{l}.37 \\
.34 \\
.33 \\
.33\end{array}$ \\
\hline $\begin{array}{l}\text { D. A..... } \ldots \ldots \ldots \ldots \ldots \\
\text { Paper XiI }(20) \ldots \ldots \ldots \ldots \\
\text { Table II } \ldots \ldots \ldots \ldots \ldots \ldots\end{array}$ & $\underset{\text { XXIII }}{\underset{\text { XXI }}{\text { XXI }}}$ & $\begin{array}{l}.29 \\
.21 \\
.30\end{array}$ & $\begin{array}{l}.31 \\
.34 \\
.31\end{array}$ & $\begin{array}{l}.60 \\
.55 \\
.61\end{array}$ & $\begin{array}{l}.68 \\
.68 \\
.68\end{array}$ & $\begin{array}{l}.10 \\
.07 \\
.07\end{array}$ & $\begin{array}{l}.50 \\
.48 \\
.45\end{array}$ & $\begin{array}{l}.60 \\
.55 \\
.52\end{array}$ & $\begin{array}{l}.34 \\
.35 \\
.35\end{array}$ \\
\hline 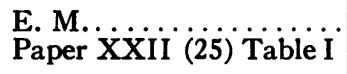 & II & $\begin{array}{l}.24 \\
.26\end{array}$ & $\begin{array}{l}.44 \\
.35\end{array}$ & $\begin{array}{l}.68 \\
.61\end{array}$ & $\begin{array}{l}.65 \\
.65\end{array}$ & $\begin{array}{l}.03 \\
.08\end{array}$ & $\begin{array}{l}.55 \\
.43\end{array}$ & $\begin{array}{l}.58 \\
.51\end{array}$ & $\begin{array}{l}.30 \\
.30\end{array}$ \\
\hline 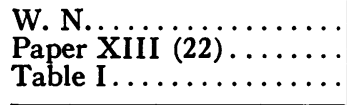 & $\begin{array}{r}\text { I } \\
\text { III }\end{array}$ & $\begin{array}{l}.12 \\
.19 \\
.21\end{array}$ & $\begin{array}{l}.31 \\
.29 \\
.31\end{array}$ & $\begin{array}{l}.43 \\
.48 \\
.52\end{array}$ & $\begin{array}{l}.59 \\
.59 \\
.60\end{array}$ & $\begin{array}{l}.24 \\
.33 \\
.38\end{array}$ & $\begin{array}{l}.39 \\
.46 \\
.54\end{array}$ & $\begin{array}{l}.63 \\
.79 \\
.92\end{array}$ & $\begin{array}{l}.29 \\
.28 \\
.28\end{array}$ \\
\hline Average for 5 subjects... & & .25 & .36 & .61 & .66 & .16 & .36 & .52 & .32 \\
\hline 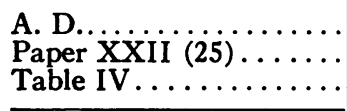 & $\underset{\mathbf{X I}}{\mathrm{IX}}$ & $\begin{array}{l}.30 \\
.28 \\
.34\end{array}$ & $\begin{array}{l}.47 \\
.45 \\
.51\end{array}$ & $\begin{array}{l}.77 \\
.73 \\
.85\end{array}$ & $\begin{array}{l}.95 \\
.80 \\
.95\end{array}$ & $\begin{array}{l}.49 \\
.43 \\
.52\end{array}$ & $\begin{array}{l}.44 \\
.37 \\
.44\end{array}$ & $\begin{array}{l}.93 \\
.80 \\
.96\end{array}$ & $\begin{array}{l}.31 \\
.27 \\
.31\end{array}$ \\
\hline 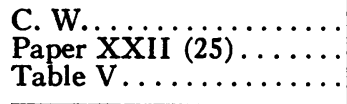 & $\underset{\mathbf{X}}{\text { VIII }}$ & $\begin{array}{l}.34 \\
.29 \\
.23\end{array}$ & $\begin{array}{l}.51 \\
.60 \\
.44\end{array}$ & $\begin{array}{l}.85 \\
.89 \\
.67\end{array}$ & $\begin{array}{l}.95 \\
.95 \\
.95\end{array}$ & $\begin{array}{l}.44 \\
.38 \\
.35\end{array}$ & $\begin{array}{l}.65 \\
.52 \\
.69\end{array}$ & $\begin{array}{r}1.09 \\
.90 \\
1.04\end{array}$ & $\begin{array}{l}.32 \\
.32 \\
.32\end{array}$ \\
\hline Average. & & .29 & .50 & .79 & .93 & .44 & .52 & .96 & .31 \\
\hline
\end{tabular}

* Some of the data on these patients have been previously reported. In order to avoid repetition, references are given to the proper paper in the "Studies of Calcium and Phosphorus Metabolism" series $(20,22,25,26)$ where figures on titratable acidity, ammonia, nitrogen, calcium, phosphorus, total base, chloride, and sulphate are recorded. The initials used for each subject are the same as in the previous publications. In these observations on magnesium, transitional periods have not been studied. The period numbers in this and in the previous texts correspond with each other.

diet higher in magnesium content, and two of them (M. L. and R. L.) also had double the usual amount of calcium in the food. On these diets, each of the four subjects showed a positive magnesium balance in the control periods. These observations indicate that an essential magnesium balance with hospital patients is obtained with approximately $220 \mathrm{mgm}$. intake per day, and that magnesium storage in active subjects may be obtained with $300 \mathrm{mgm}$. per day. These may not be minimal values. This adequacy of magnesium in the food may obscure positive findings in control periods, but should not interfere with interpretations during the shifting conditions of a prolonged experiment.

\section{The addition of magnesium to the diet}

While on this adequate magnesium diet, two of our normal subjects (M. L. and R. L.) were given 8 to 10 grams of magnesium lactate a day for twelve days. During this time the excretion of magnesium was naturally increased as may be seen in Tables II and III. This increase is found in both urine and feces though, as with calcium, the greater amount of the increase is in the feces, except that in R. L. (Table III) the usual urine: feces ratio is fairly closely maintained. It is clear then that magnesium lactate can be absorbed. Its excretion, like that of calcium, is not rapid for the levels remain elevated in the first control periods following ingestion. It is inter- 


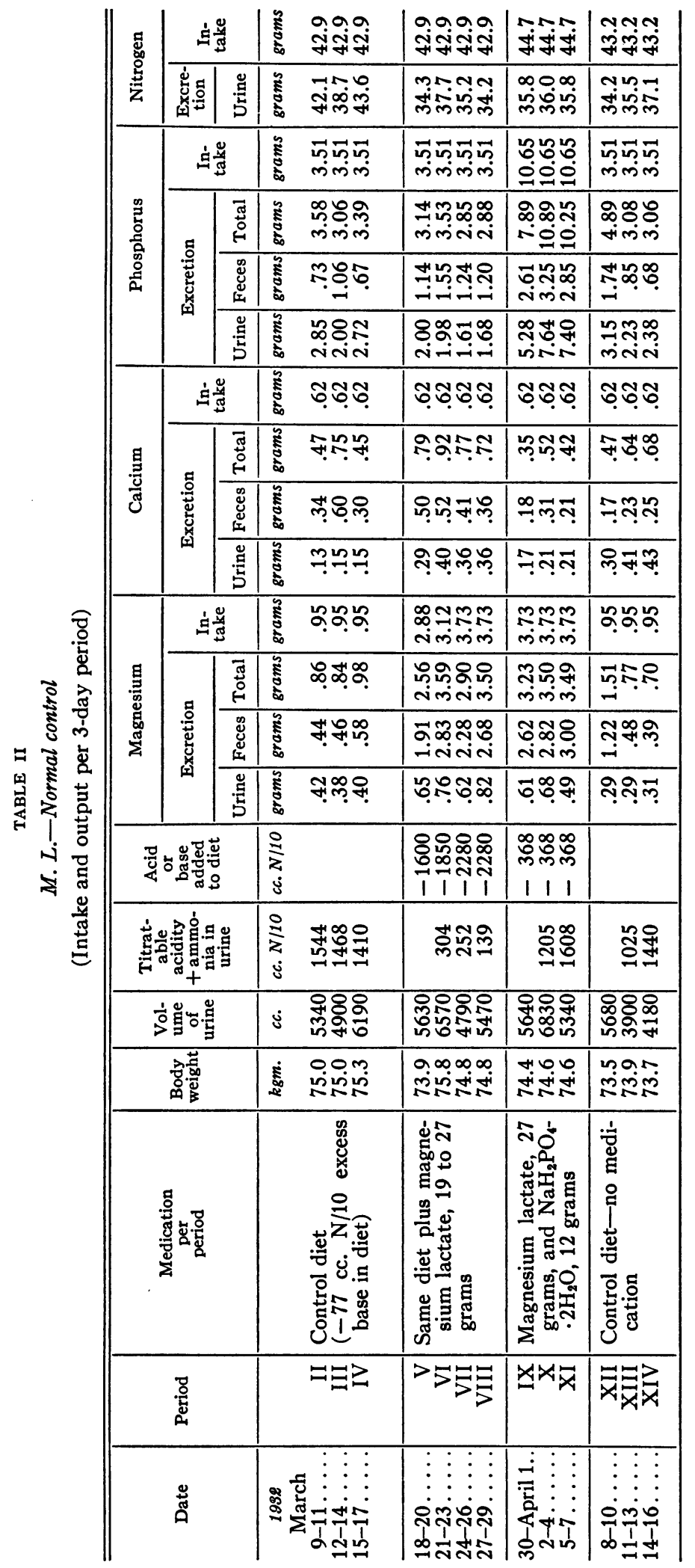

\begin{tabular}{|c|c|c|}
\hline 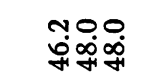 & | & พ゙ฯ \\
\hline 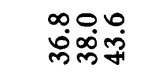 & 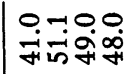 & 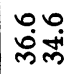 \\
\hline 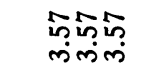 & 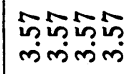 & iñ \\
\hline $\begin{array}{l}\because \dddot{\infty} \\
\text { mं் }\end{array}$ & 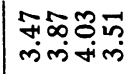 & $\begin{array}{l}\text { के } \\
\text { im }\end{array}$ \\
\hline ธฺฺฺุ & mân & సִ \\
\hline 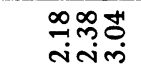 & 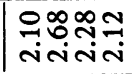 & $\mid$\begin{tabular}{c}
$\hat{6}$ \\
\hdashline$\underset{1}{*}$
\end{tabular} \\
\hline :ํํํ & 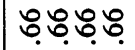 & :ํ. \\
\hline 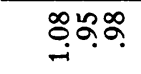 & |운윰원 & $\stackrel{n}{m}$ \\
\hline 분ํํㄴ & 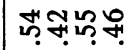 & : \\
\hline จุจุกิ & 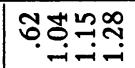 & ऩ⿳亠口冋. \\
\hline ஜํํำ & 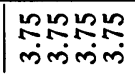 & 20 \\
\hline గొం & 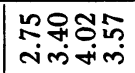 & బ़् \\
\hline 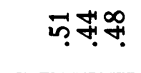 & 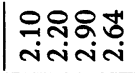 & 풍 \\
\hline "ైలిొొొ & ทํ్తిస్తి & 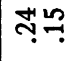 \\
\hline 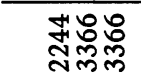 & ్్ా్లెల్ల్ల్ల్ల్ల & \\
\hline ชైซ్ & 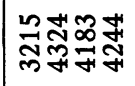 & 总 \\
\hline 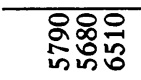 & 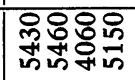 & 앙్ా \\
\hline $\begin{array}{l}\text { åa } \\
\text { minm }\end{array}$ & 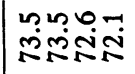 & min \\
\hline 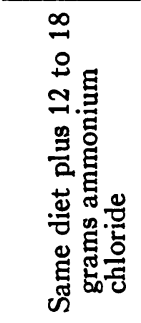 & 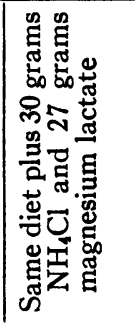 & 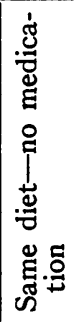 \\
\hline 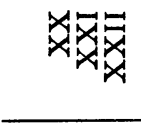 & 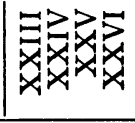 & 四品 \\
\hline 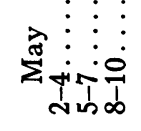 & 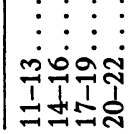 & 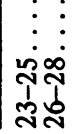 \\
\hline
\end{tabular}


MAGNESIUM METABOLISM. I

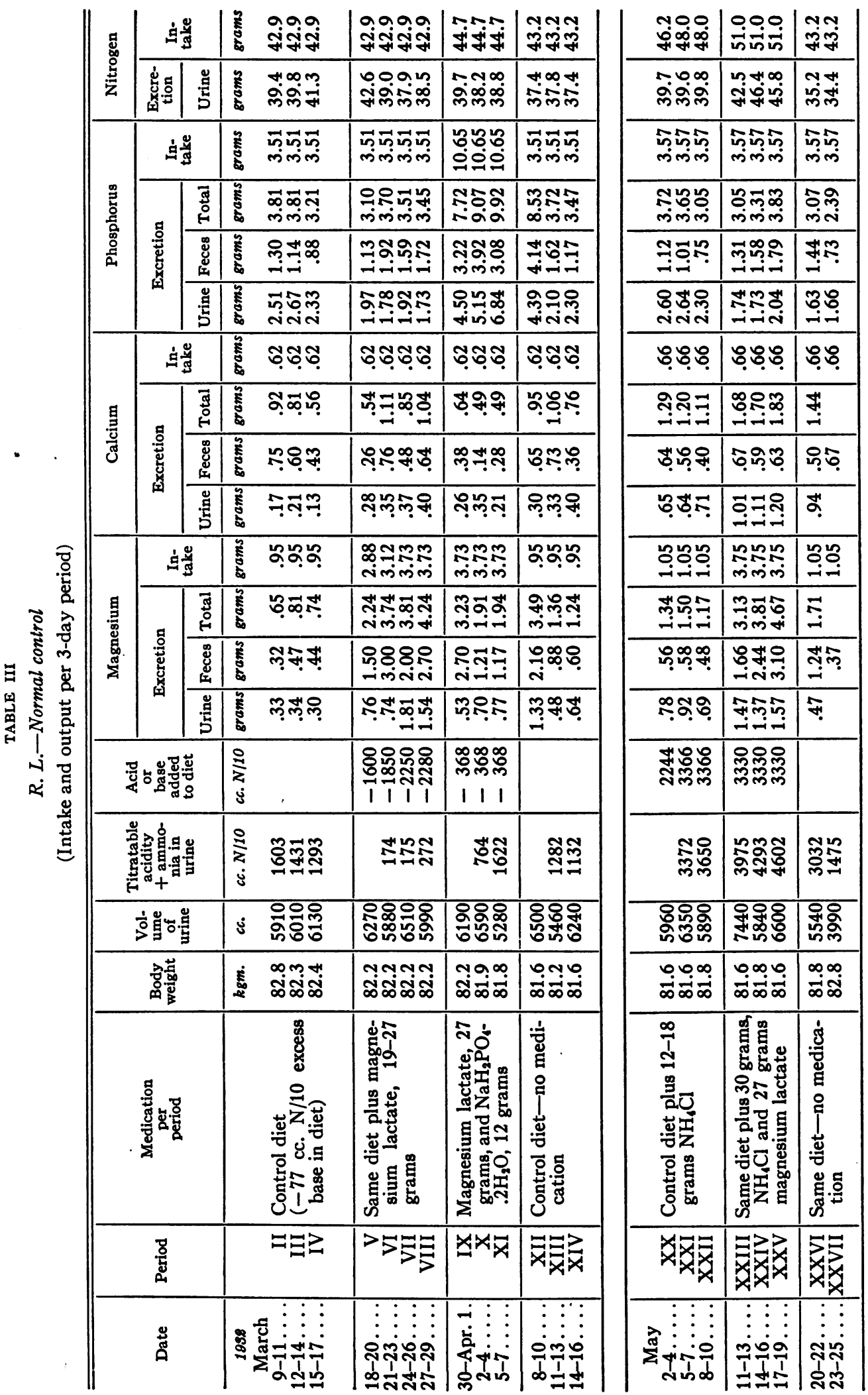


esting, however, that in one of these young men (R. L.) the increased ingestion of magnesium resulted in a negative balance, while in the case of the other subject an average of over $200 \mathrm{mgm}$. per period was retained. Carswell and Winter (14) on feeding magnesium lactate to two normal men found a greater retention of magnesium in one case than in the other, but both stored more than did our subjects. From clinical experience with magnesium sulphate, one might expect some such variation in the absorption of magnesium from the gastro-intestinal tract.

Mendel and Benedict (15) first linked together magnesium and calcium excretion. They showed that parenteral injections of salts of either base increased the urinary excretion of both bases. The effect of oral administration has not been so clearly demonstrated, and the literature on the subject gives conflicting data $(16,17,18)$. Carswell and Winter (14) and Barbour and Winter (19) report that the oral administration of magnesium lactate causes a retention of calcium in the presence of an adequate amount of phosphorus.

Evidence in regard to this problem can be seen clearly in the first part of the observations on the two normal medical students (Tables II and III). The addition of the potentially alkaline magnesium lactate, taken by mouth, was accompanied by an increased calcium as well as magnesium excretion in the urine. This is particularly interesting for in our previous studies (20) an alkaline intake has been associated with only an occasional slight urinary increase in calcium output. The stimulating effect of magnesium ingestion on calcium metabolism is even more marked in the subsequent experiment (Periods XXIII to XXVI) when calcium elimination had already been stimulated by the ingestion of ammonium chloride. The addition of magnesium lactate, plus enough added $\mathrm{NH}_{4} \mathrm{Cl}$ to maintain approximately the same dietary acidity as in the preceding periods greatly increased both the calcium and magnesium in the urine. It is clear, therefore, that the increased calcium excretion following magnesium lactate here, and following magnesium gluconate in F. G. (see Paper II of this series (21)) is due to the effect of the magnesium ion. (The interrelationship of phosphate is discussed later in this paper.)

\section{The effect of acid ingestion}

The effect of acid ingestion on calcium metabolism is well known. Phosphoric acid ions have little effect (22) but other anions and acid-producing salts, like ammonium chloride, elevate the calcium elimination distinctly (20). Physiologically, the problem is facilitated by the storehouse of readily available calcium in the trabeculae of bone (23). The calcium, which is excreted because of acid ingestion, we have shown comes largely from these bone trabeculae, but little magnesium is stored there. It is, therefore, of interest to see whether the effects of acids on magnesium and calcium are the same; whether bases can be drawn from soft tissues as well as bone to buffer acid ingestion. From the chemical point of view one might expect magnesium to be so influenced. The effect of these anions 'on magnesium metabolism has, therefore, been investigated.

Table IV shows the effect of acid ingestion on the magnesium elimination of four subjects. Other studies on these patients have been previously reported, and in order to avoid repetition, references are given in the tables to the papers where additional data may be found.

Patient A. N., aged 16, weighing 34 kilos, had a marked structural scoliosis and was first studied previous to operation. After being on a control neutral low calcium diet for 21 days he was given a diet with a potential acidity of about $700 \mathrm{cc}$. $\mathrm{N} / 10$ per day. After nine days he was given the original control diet to which was added 6 grams $\mathrm{NH}_{4} \mathrm{Cl}$ daily. Both the acid diet and the potentially acid salt raised the urinary calcium to a marked degree but the effect upon the magnesium excretion was slight. During his second admission, six months after a spinal fusion, his normal calcium output was greatly reduced, and he was in positive rather than negative balance in respect to magnesium. On the ingestion of $\mathrm{NH}_{4} \mathrm{Cl}$ his urinary excretion of calcium was again raised fourfold and there was an increase in urinary magnesium, though not in the total magnesium excretion.

Patient D. A., aged 37, weighing 58 kilos, was studied while recovering from lead poisoning. $\mathrm{He}$ was given 8 grams of $\mathrm{NH}_{4} \mathrm{Cl}$ daily for six days, followed by two periods with 12 grams per day. As the acid effect of this salt as indicated by 
TABLE IV *

Effect of acid ingestion

(Intake and output in 3-day periods)

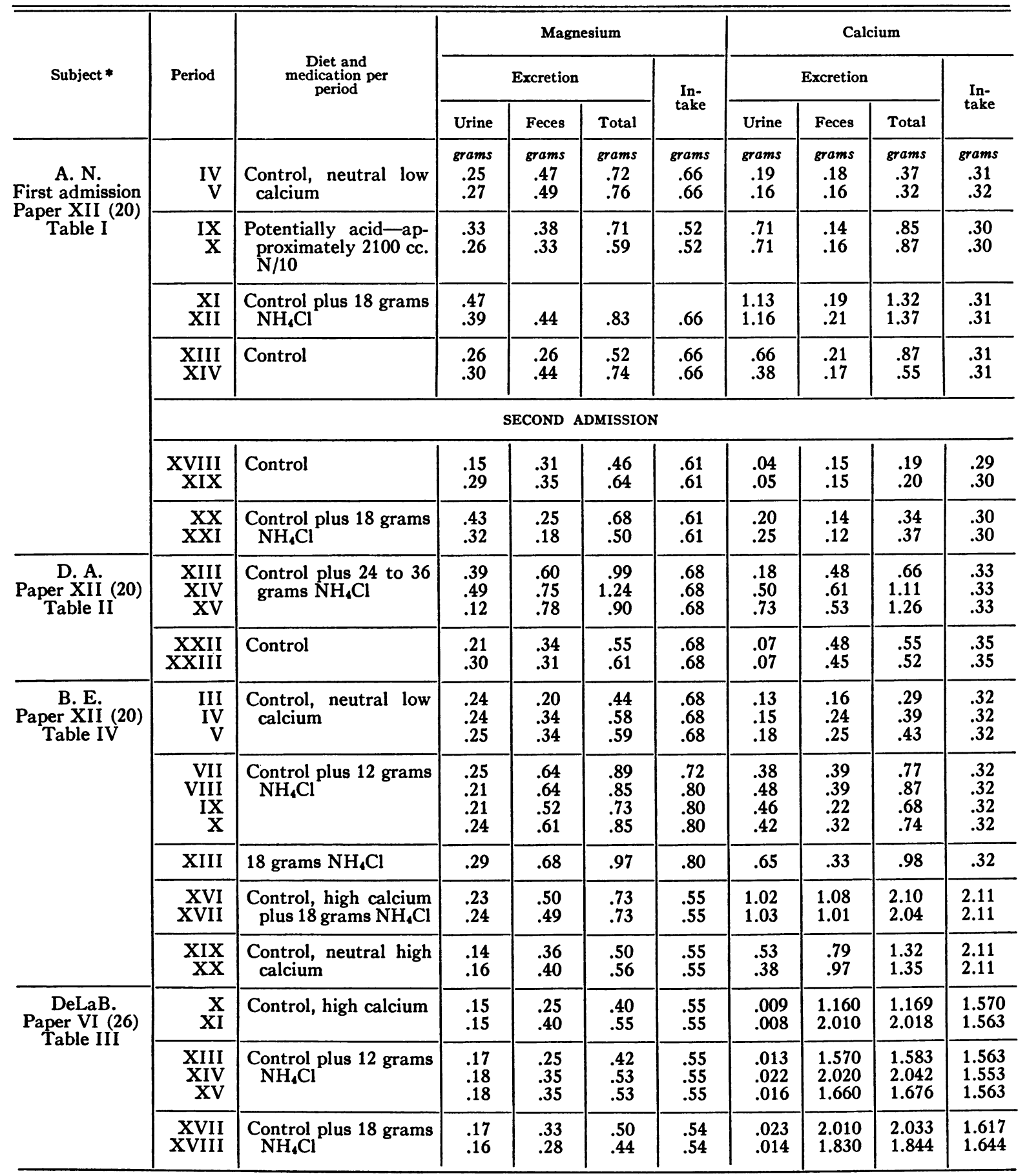

* See footnote to Table I. 
the urinary output of ammonia (24) persisted on into the following periods, these have been omitted in our study on magnesium excretion and two later ones used as control periods. As will be seen from Table IV, the magnesium excretion during $\mathrm{NH}_{4} \mathrm{Cl}$ ingestion is greater in both urine and feces than during the two periods on diet alone. The elevation, however, is not so great as that of calcium which was limited to the urinary excretion.

Patient B. E., aged 58, weighing 55 kilos, suffering from chronic sciatic neuritis, was studied while on both a low and a high calcium diet. The addition of $\mathrm{NH}_{4} \mathrm{Cl}$ to either diet caused a marked elevation of urinary calcium excretion. The high calcium diet, however, stopped the negative calcium balance, and calcium was actively stored during the control high calcium periods. The magnesium metabolism was also affected in these observations. In spite of a slight increase in the intake of magnesium during the periods of $\mathrm{NH}_{4} \mathrm{Cl}$ ingestion, the patient showed a negative magnesium balance in contrast to the control periods when magnesium was stored. In the second observation, made during a high calcium and a lower magnesium intake, the excretion of magnesium is on a distinctly lower level, but still shows the stimulating effect of acid ingestion in spite of the fact that the patient was in calcium balance. The interesting point of this experiment is that when the loss of body fixed base was practically stopped by additions of calcium to the diet, the excretion of magnesium could still be stimulated.

In $D e L a B$., a patient with steatorrhea and tetany, the ingestion of ammonium chloride resulted in no pronounced elevation of either calcium or magnesium excretion.

The two medical students (M. L., Table II, and R. L., Table III), were also given ammonium chloride. While the urinary calcium excretion of both was increased, the excretion of magnesium was elevated in only one case, $R$. L., that of M. L. remaining unaffected.

These observations on the effect of the acidproducing salt, ammonium chloride, indicate that magnesium may be used in the body as base, the excess usually appearing in the urine. The amount used is of a smaller magnitude than that of calcium. The amount, however, is too large to ascribe the source of magnesium to bone alone, and therefore some of it must come from soft tissues. Several of our observations, however, showed that their reaction is not always parallel and that calcium alone could be elevated without influencing magnesium. Likewise, magnesium may be used as base in processes of excretion even if an adequate amount of calcium to produce a positive calcium balance is given in the diet.

\section{The effect of ingestion of phosphate}

In a previous paper (22) it was shown that sodium acid phosphate differed from other acidproducing substances in that it did not increase the excretion of ammonia or calcium in the urine. It was also shown that the ingestion of large amounts of phosphorus either as inorganic salts or as protein had no appreciable effect upon the calcium balance, when the acid effect of the protein was controlled by sodium bicarbonate. Since phosphorus and magnesium are present in fairly large quantities in all body tissues, it would seem not unlikely that the metabolism of one might affect that of the other. It was, therefore, of interest to study the effect of the ingestion and storage of phosphorus upon the metabolism of magnesium. The results of these observations may be seen in Table V.

Patient $W$. N., aged 34, was suffering from chronic atrophic arthritis. After three control periods, $\mathbf{1 5}$ grams of sodium acid phosphate were added to her potentially neutral low calcium diet daily for seven days. No effect on magnesium excretion in urine or feces was obvious.

In Patient D. A., the ingestion of 15 grams of sodium acid phosphate daily for six days resulted in a slightly lower urinary excretion of magnesium than was present in the following control periods though the total excretion of magnesium was practically the same in all periods.

From these two observations, it would seem that the ingestion of acid sodium phosphate has no more effect upon magnesium excretion than upon that of calcium.

Patient L. $Z$., aged 18, recovering from chronic multiple neuritis, was studied while on a higher calcium intake than most of our other patients. The effect of a high meat diet, the acidity of which was buffered by means of $\mathrm{NaHCO}_{3}$, was first studied. On this diet, urinary calcium was 
TABLE $v^{*}$

Effect of phosphate ingestion

(Intake and output in 3-day periods)

\begin{tabular}{|c|c|c|c|c|c|c|c|c|c|c|c|c|}
\hline \multirow{3}{*}{ Subject* } & \multirow{3}{*}{ Period } & \multirow{3}{*}{$\begin{array}{c}\text { Diet and } \\
\text { medication per } \\
\text { period }\end{array}$} & \multicolumn{4}{|c|}{ Magnesium } & \multicolumn{4}{|c|}{ Calcium } & \multicolumn{2}{|c|}{ Phosphorus } \\
\hline & & & \multicolumn{3}{|c|}{ Excretion } & \multirow{2}{*}{$\begin{array}{l}\text { In- } \\
\text { take }\end{array}$} & \multicolumn{3}{|c|}{ Excretion } & \multirow{2}{*}{$\begin{array}{l}\text { In- } \\
\text { take }\end{array}$} & \multirow{2}{*}{$\begin{array}{c}\text { To- } \\
\text { tal } \\
\text { excre- } \\
\text { tion }\end{array}$} & \multirow{2}{*}{$\underset{\text { take }}{\text { In- }}$} \\
\hline & & & Urine & Feces & Total & & Urine & Feces & Total & & & \\
\hline \multirow[t]{3}{*}{$\underset{\text { Table I }}{\text { W. N. }}$} & II & Control & $\begin{array}{c}\text { grams } \\
.12 \\
.19 \\
.21\end{array}$ & $\begin{array}{c}\text { grams } \\
.31 \\
.29 \\
.31\end{array}$ & $\begin{array}{r}\text { grams } \\
.43 \\
.48 \\
.52\end{array}$ & $\begin{array}{r}\text { grams } \\
.59 \\
.59 \\
.60\end{array}$ & $\begin{array}{c}\text { grams } \\
.24 \\
.33 \\
.38\end{array}$ & $\begin{array}{c}\text { grams } \\
.39 \\
.46 \\
.54\end{array}$ & $\begin{array}{c}\text { grams } \\
.63 \\
.79 \\
.92\end{array}$ & $\begin{array}{c}\text { grams } \\
.29 \\
.28 \\
.28\end{array}$ & $\begin{array}{l}\text { grams } \\
1.66 \\
1.82 \\
1.99\end{array}$ & $\begin{array}{r}\text { grams } \\
1.85 \\
1.87 \\
1.86\end{array}$ \\
\hline & $\begin{array}{c}I V \\
V \\
\text { VI }\end{array}$ & $\begin{array}{l}\text { Control plus } 10 \text { to } 45 \\
\text { grams } \mathrm{NaH}_{2} \mathrm{PO}_{4} \cdot \mathrm{H}_{2} \mathrm{O}\end{array}$ & $\begin{array}{l}.21 \\
.30 \\
.11\end{array}$ & $\begin{array}{l}.26 \\
.28 \\
.31\end{array}$ & $\begin{array}{l}.47 \\
.58 \\
.42\end{array}$ & $\begin{array}{l}.60 \\
.60 \\
.60\end{array}$ & $\begin{array}{l}.36 \\
.26 \\
.33\end{array}$ & $\begin{array}{l}.49 \\
.55 \\
.41\end{array}$ & $\begin{array}{l}.85 \\
.81 \\
.74\end{array}$ & $\begin{array}{l}.28 \\
.28 \\
.28\end{array}$ & $\begin{array}{l}2.80 \\
8.46 \\
8.83\end{array}$ & $\begin{array}{r}3.85 \\
10.84 \\
10.84\end{array}$ \\
\hline & VIII & Control & $\begin{array}{l}.07 \\
.09\end{array}$ & $\begin{array}{l}.38 \\
.39\end{array}$ & $\begin{array}{l}.45 \\
.48\end{array}$ & $\begin{array}{l}.59 \\
.60\end{array}$ & $\begin{array}{l}.20 \\
.33\end{array}$ & $\begin{array}{l}.61 \\
.67\end{array}$ & $\begin{array}{r}.81 \\
1.00\end{array}$ & $\begin{array}{l}.27 \\
.28\end{array}$ & $\begin{array}{l}1.48 \\
2.02\end{array}$ & $\begin{array}{l}1.85 \\
1.87\end{array}$ \\
\hline \multirow{2}{*}{$\begin{array}{l}\text { D. A. } \\
\text { Paper XIII (22) } \\
\text { Table III }\end{array}$} & $\underset{\mathbf{X X}}{\mathbf{X I X}}$ & $\begin{array}{l}\text { Control plus } 12 \text { grams } \\
\mathrm{NaH}_{2} \mathrm{PO}_{4} \cdot \mathrm{H}_{2} \mathrm{O}\end{array}$ & $\begin{array}{l}.14 \\
.18\end{array}$ & $\begin{array}{l}.37 \\
.43\end{array}$ & $\begin{array}{l}.51 \\
.61\end{array}$ & $\begin{array}{l}.68 \\
.68\end{array}$ & $\begin{array}{l}.07 \\
.06\end{array}$ & $\begin{array}{l}.33 \\
.56\end{array}$ & $\begin{array}{l}.40 \\
.62\end{array}$ & $\begin{array}{l}.33 \\
.34\end{array}$ & $\begin{array}{l}7.58 \\
9.73\end{array}$ & $\begin{array}{l}10.14 \\
10.14\end{array}$ \\
\hline & $\underset{\text { XXIII }}{\text { XXI }}$ & Control & $\begin{array}{l}.29 \\
.21 \\
.30\end{array}$ & $\begin{array}{l}.31 \\
.34 \\
.31\end{array}$ & $\begin{array}{l}.60 \\
.55 \\
.61\end{array}$ & $\begin{array}{l}.68 \\
.68 \\
.68\end{array}$ & $\begin{array}{l}.10 \\
.07 \\
.07\end{array}$ & $\begin{array}{l}.50 \\
.48 \\
.45\end{array}$ & $\begin{array}{l}.60 \\
.55 \\
.52\end{array}$ & $\begin{array}{l}.34 \\
.35 \\
.35\end{array}$ & $\begin{array}{l}3.88 \\
1.91 \\
1.69\end{array}$ & $\begin{array}{l}3.04 \\
2.15 \\
2.15\end{array}$ \\
\hline \multirow{5}{*}{$\begin{array}{c}\text { L. Z. } \\
\text { Paper XIII (22) } \\
\text { Table V }\end{array}$} & II & Control & $\begin{array}{l}.37 \\
.42\end{array}$ & $\begin{array}{l}.31 \\
.23\end{array}$ & $\begin{array}{l}.68 \\
.65\end{array}$ & $\begin{array}{l}.58 \\
.58\end{array}$ & $\begin{array}{l}1.04 \\
1.01\end{array}$ & $\begin{array}{r}1.23 \\
.67\end{array}$ & $\begin{array}{l}2.27 \\
1.68\end{array}$ & $\begin{array}{l}1.54 \\
1.52\end{array}$ & $\begin{array}{l}2.41 \\
2.44\end{array}$ & $\begin{array}{l}2.09 \\
2.09\end{array}$ \\
\hline & $\begin{array}{r}\mathrm{IV} \\
\mathrm{V} \\
\mathrm{VI} \\
\mathrm{VII} \\
\mathrm{VIII}\end{array}$ & $\begin{array}{l}\text { High protein plus } \\
\mathrm{NaHCO}_{3}\end{array}$ & $\begin{array}{l}.30 \\
.28 \\
.28 \\
.19 \\
.34\end{array}$ & $\begin{array}{r}1.08 \\
.93 \\
1.05 \\
1.31 \\
.90\end{array}$ & $\begin{array}{l}1.38 \\
1.21 \\
1.33 \\
1.50 \\
1.24\end{array}$ & $\begin{array}{r}1.14 \\
1.12 \\
1.12 \\
.82 \\
.98\end{array}$ & $\begin{array}{r}1.20 \\
.80 \\
.98 \\
.99 \\
1.11\end{array}$ & $\begin{array}{l}1.59 \\
1.38 \\
1.40 \\
1.73 \\
1.13\end{array}$ & $\begin{array}{l}2.79 \\
2.18 \\
2.38 \\
2.72 \\
2.24\end{array}$ & $\begin{array}{l}1.55 \\
1.55 \\
1.55 \\
1.19 \\
1.41\end{array}$ & $\begin{array}{l}7.09 \\
5.84 \\
6.38 \\
5.93 \\
6.28\end{array}$ & $\begin{array}{l}6.15 \\
5.66 \\
5.65 \\
4.83 \\
5.29\end{array}$ \\
\hline & $\underset{\mathbf{X I}}{\mathrm{X}}$ & Control & $\begin{array}{l}.40 \\
.38\end{array}$ & $\begin{array}{l}.35 \\
.63\end{array}$ & $\begin{array}{r}.75 \\
1.01\end{array}$ & $\begin{array}{l}.58 \\
.58\end{array}$ & $\begin{array}{r}1.12 \\
.91\end{array}$ & $\begin{array}{r}.87 \\
1.46\end{array}$ & $\begin{array}{l}1.99 \\
2.37\end{array}$ & $\begin{array}{l}1.48 \\
1.55\end{array}$ & $\begin{array}{l}3.21 \\
3.11\end{array}$ & $\begin{array}{l}2.05 \\
2.09\end{array}$ \\
\hline & $\begin{array}{r}\text { XII } \\
\text { XIII } \\
\text { XIV }\end{array}$ & $\begin{array}{l}\text { Control plus } \\
\mathrm{NaH}_{2} \mathrm{PO}_{4} \cdot \mathrm{H}_{2} \mathrm{O} \text { and } \\
\mathrm{Na}_{2} \mathrm{HPO}_{4} \cdot 12 \mathrm{H}_{2} \mathrm{O}\end{array}$ & $\begin{array}{l}.31 \\
.22 \\
.17\end{array}$ & $\begin{array}{l}.26 \\
.52 \\
.48\end{array}$ & $\begin{array}{l}.57 \\
.74 \\
.65\end{array}$ & $\begin{array}{l}.58 \\
.55 \\
.53\end{array}$ & $\begin{array}{l}.86 \\
.63 \\
.42\end{array}$ & $\begin{array}{l}.56 \\
2.15 \\
1.09\end{array}$ & $\begin{array}{l}1.42 \\
2.78 \\
1.51\end{array}$ & $\begin{array}{l}1.52 \\
1.49 \\
1.53\end{array}$ & $\begin{array}{l}3.95 \\
5.24 \\
4.69\end{array}$ & $\begin{array}{l}5.39 \\
5.36 \\
5.39\end{array}$ \\
\hline & $\underset{\mathrm{XVI}}{\mathrm{XV}}$ & Control & $\begin{array}{l}.28 \\
.34\end{array}$ & .39 & .73 & $\begin{array}{l}.53 \\
.57\end{array}$ & $\begin{array}{l}.76 \\
.85\end{array}$ & $\begin{array}{r}1.00 \\
.97\end{array}$ & $\begin{array}{l}1.76 \\
1.82\end{array}$ & $\begin{array}{l}1.52 \\
1.53\end{array}$ & $\begin{array}{l}2.10 \\
1.73\end{array}$ & $\begin{array}{l}2.09 \\
2.09\end{array}$ \\
\hline
\end{tabular}

* See footnote to Table I.

unaffected, but fecal calcium was increased. The effect on the magnesium excretion is more difficult to evaluate because of the increased ingestion involved in its high concentration in meat. In spite of this, the negative magnesium balance was increased in the feces sufficiently to make a more negative balance than in the control. In Periods XII to XIV the phosphorus intake of this patient was raised to approximately that of the high protein diet by the addition to the control diet of an equimolecular mixture of acid and basic sodium phosphates. During these periods, when phosphorus was being stored, the loss of calcium and magnesium continued as in the control periods although the excretion shifted slightly from the urinary to the fecal route.

From the above observations, it is clear that magnesium exchange is not greatly affected by the ingestion of large amounts of phosphate and that storage of phosphorus is not necessarily accompanied by retention of magnesium or calcium.

However, a different 'situation arises when inorganic phosphates are added to a diet already very high in magnesium. This can be seen in the observations on the two medical students (M. L. and R. L., Tables II and III). As has already been noted, the addition of magnesium lactate to their adequate phosphate diet definitely 
increased the excretion of calcium in their urines. When enough acid phosphate to buffer the large magnesium intake was added to the diet, there was an immediate change from a negative to a positive balance of calcium. This calcium storage was promptly lost after stopping the excess phosphorus and magnesium ingestion. In regard to the magnesium balance there is no such consistency, for in R. L. (Table III) the magnesium and calcium are similarly influenced, but the addition of phosphates to the diet of M..L. (Table II) caused no significant alteration in magnesium retention.

It is, therefore, clear that the addition of phosphates to the diet does not increase magnesium or calcium excretion; in fact, phosphate ingestion prevents the stimulation of calcium excretion which is produced by large magnesium ingestion.

\section{SUMMARY}

1. Magnesium balance was obtained with hospital patients on an intake of $220 \mathrm{mgm}$. per day and magnesium storage in active subjects on 300 mgm. per day. These may not be minimal values.

2. There is parallelism of calcium and magnesium metabolism in response to the ingestion of $\mathrm{NH}_{4} \mathrm{Cl}$ and both inorganic and organic phosphates.

3. The changes, however, in magnesium metabolism are of much less magnitude than those of calcium, but they are larger than can be accounted for by the amount of magnesium in bone. From this it is apparent that an intracellular kation can be used for neutralizing excess acid ions in urine.

4. Increased 'magnesium lactate ingestion resulted in an increase in the urinary excretion of calcium, a response which was checked by large intake of sodium acid phosphate.

Magnesium lactate accentuated the effect of ammonium chloride in elevating urinary calcium excretion. It is, therefore, clear that magnesium ingestion increases calcium elimination.

\section{BIBLIOGRAPHY}

1. Kruse, H. D., Orent, E. R., and McCollum, E. V., Studies on magnesium deficiency in animals. $I$. Symptomatology resulting from magnesium deprivation. J. Biol. Chem., 1932, 96, 519.

Orent, E. R., Kruse, H. D., and McCollum, E. V., Studies on magnesium deficiency in animals. II. Species variation in symptomatology of magnesium deprivation. Am. J. Physiol., 1932, 101, 454.
2. Schmidt, C. L. A., and Greenberg, D. M., Occurrence, transport and regulation of calcium, magnesium and phosphorus in the animal organism. Physiol. Rev., 1935, 15, 297.

3. Magnus-Levy, A., Utber den Gehalt normaler menschlicher Organe an Chlor, Calcium, Magnesium, und Eisen sowie an Wasser Eiweiss und Fett. Biochem. Ztschr., 1910, 24, 363.

4. Cullen, G. E., Wilkins, W. E., and Harrison, T. R., Electrolytes in human tissue. II. The electrolyte content of hearts and other tissues from cases with various diseases. J. Biol. Chem., 1933, 102, 415.

5. Sherman, H. C., Chemistry of Food and Nutrition. The Macmillan Company, New York, 1933. 4th ed.

6. Greenberg, D. M., Lucia,-S. P., Mackey, M. A., and Tufts, E. V., The magnesium content of the plasma and the red corpuscles in human blood. J. Biol. Chem., 1933, 100, 139.

7. McCrudden, F. H., Metabolism in Diseases of the Bones and Joints. In Endocrinology and Metabolism. Vol. IV. D. Appleton and Company, New York, 1922, p. 741.

8. Euler, H. von, and Rydbom, M., Uber den Einfluss von Magnesiumsalzen auf Knochenbildung und Rachitis. I. Biochem. Ztschr., 1931, 241, 14.

9. Morgulis, S., Studies on the chemical composition of bone ash. J. Biol. Chem., 1931, 93, 455.

10. Benedict, F. G., A Study of Prolonged Fasting. Carnegie Institute of Washington, 1915, Publication 203.

11. Bauer, W., and Aub, J. C., Studies of inorganic salt metabolism. I. The ward routine and methods. J. Am. Dietet. A., 1927, 3, 106.

12. Folin, O., Laboratory Manual of Biological Chemistry. D. Appleton-Century Co., New York, 1934, 5th ed.

13. Fiske, C. H., and Logan, M. A., The determination of calcium by alkalimetric titration. II. The precipitation of calcium in the presence of magnesium, phosphate, and sulfate, with applications to the analysis of urine. J. Biol. Chem., 1931, 93, 211.

14. Carswell, H. E., and Winter, J. E., The effects of high and prolonged magnesium lactate intake upon the metabolism of magnesium and calcium in man. J. Biol. Chem., 1931, 93, 411.

15. Mendel, L. B., and Benedict, S. R., The paths of excretion for inorganic compounds. IV. The excretion of magnesium. Am. J. Physiol., 1909, 25, 1.

Mendel, L. B., and Benedict, S. R., The paths of excretion for inorganic compounds. V. The excretion of calcium. Am. J. Physiol., 1909, 25, 23.

16. Hart, E. B., and Steenbock, H., The effect of a high magnesium intake on calcium retention by swine. J. Biol. Chem., 1913, 14, 75.

17. Givens, M. H., Studies in calcium and magnesium metabolism. IV. Experiments on man. J. Biol. Chem., 1918, 34, 119.

18. Bogert, L. J., and McKittrick, E. J., Studies in inor- 
ganic metabolism. I. Interrelations between calcium and magnesium metabolism. J. Biol. Chem., 1922, 54, 363.

19. Barbour, H. G., and Winter, J. E., Magnesium absorption in dogs and its effect upon the metabolism of calcium. J. Pharmacol. and Exper. Therap., $1931,43,607$.

20. Farquharson, R. F., Salter, W. T., Tibbetts, D. M., and Aub, J. C., Studies of calcium and phosphorus metabolism. XII. The effect of the ingestion of acid-producing substances. J. Clin. Invest., 1931, 10, 221.

21. Tibbetts, D. M., and Aub, J. C., Magnesium metabolism in health and disease. II. The effect of the parathyroid hormone. J. Clin. Invest., 1937, 16, 503.

22. Farquharson, R. F., Salter, W. T., and Aub, J. C., Studies of calcium and phosphorus metabolism. XIII. The effect of ingestion of phosphates on the excretion of calcium. J. Clin. Invest., 1931, 10, 251.
23. Bauer, W., Aub, J. C., and Albright, F., Studies of calcium and phosphorus metabolism. V. A study of the bone trabeculae as a readily available reserve supply of calcium. J. Exper. Med., 1929, 49, 145.

24. Salter, W. T., Farquharson, R. F., and Tibbetts, D. M., Studies of calcium and phosphorus metabolism. XIX. The effect of diet on urinary acid and ammonia excretion in man. J. Lab. and Clin. Med., 1933, 18, 669.

25. Aub, J. C., Tibbetts, D. M., and McLean, R., Studies of calcium and phosphorus metabolism. XXII. The influence of parathyroid hormone, urea, sodium chloride, fat, and of intestinal activity upon calcium balance. J. Nutrition, 1937, 13, 635.

26. Aub, J. C., Albright, F., Bauer, W., and Rossmeisl, E., Studies of calcium and phosphorus metabolism. VI. In hypoparathyroidism and chronic steatorrhea with tetany with special consideration of the therapeutic effect of thyroid. J. Clin. Invest., 1932, 11, 211. 